\section{Kongemordet 1286 i ny belysning}

\author{
afprofessor, dr.phil. Thomas Riis,
} Kiels Universitet

\section{5. april 2013 prosenterede Dansk} Center for Musikudgivelse ved Det Kongelige Bibliotek den nye kritisk-videnskabelige udgave af komponisten Peter Heises (18301879) store nationalromantiske operadrama Drot og Marsk om mordet på kong Erik Glipping d. 22. november $1286 .{ }^{1}$

Til den lejlighed holdt én af Danmarks forende middelalderhistorikere, professor emeritus Thomas Riis, på Det Kongelige Biblioteks opfordring et foredrag om, hvad vi egentlig ved og de forskellige svar gennem tiden på sporgsmålet om, hvem morderne var, og hvem der i ovrigt stod bag. Foredraget bringes her lettere redigeret.

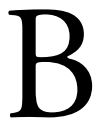

aggrunden for operaen Drot og Marsk er en af de uløste gåder i Danmarks historie - hvorfor blev kong Erik 5. Glipping myrdet i Skt. Cæcilienat mellem den 21. og 22. november 1286 og af hvem? Marsk Stig Andersen Hvide blev sammen med en række andre anklaget og dømt for mordet; men var det et justitsmord eller en korrekt proces?

Emnet er flere gange blevet behandlet i litteraturen, først i folkeviserne, senere i skuespil og romaner. For Adam Oehlenschläger (1779-1850) havde hver af de sammensvorne sit eget motiv til at myrde kongen, medens Marsk Stig ville nøjes med at duellere med kongen for at redde sin ære, da det kunne se ud som om kongen havde forført hans hustru. Carsten Hauch (1790-1872) og Christian Richardt
(1831-1892) tillægger som Oehlenschläger kongemorderne forskellige motiver, for marsken er der nu tale om hævn, da kongen virkelig havde forført fru Ingeborg. Hos Oehlenschläger og Hauch tegnes Rane Jonsen som en falsk og ondskabsfuld person i slægt med Jago i Othello, og i operaen viser fru Ingeborgs genfærd sig for at stævne kongen til doms; hun optræder her i samme funktion som stengæsten $i$ Don Giovanni. Alle tre skuespil bygger i sidste instans på B.S. Ingemanns roman Erik Menveds Barndom fra 1828.

I Ebbe Kløvedal Reichs Festen for Cacilie. Den hemmelige beretning om et kongemord (1979), er det en international orden, der står bag kongemordet som et skridt på vejen til den evige Verdensstat. Endelig identificerede den aarhusianske juraprofessor Jørgen Matthiassen i sin kriminalroman Blodnatten (1988) morderen med drost Peder Nielsen Hoseøl; men denne bog kom mig først i hænde, efter at jeg havde afsluttet min egen undersøgelse.

Hvordan har faghistorikerne set på sagen? Blandt de egentlige nyere historiske værker finder vi den store fremstilling af senmiddelalderens historie, som Kr. Erslev skrev i Danmarks Riges Historie omkring 1900. Grundlæggeren af den moderne kildekritik i Danmark fandt, at dommen for kongemordet var formelt ukorrekt; hans videnskabelige korrekthed forbød ham at benytte Otto Baches berømte maleri (c. 1880-82) af kongemorderne, der rider fra Finderup Lade, som illustration, og han nøjedes derfor med at gengive Baches skitser af landskabet omkring Finderup. Erik Arup fandt i sin Danmarkshistorie fra 1932 dels, at motivet til mordet var ukendt, dels at den uretfærdige dom var et opgør med systemskiftets mænd. 
Også Erik Kjersgaard så i Politikens Danmarkshistorie fra 1963 som Arup regeringsskiftet i 1282 som et systemskifte og fandt, at dommen over de angivelige kongemordere var et justitsmord. Hvis denne gruppe virkelig havde dræbt kongen, måtte dens medlemmer være sindsforvirrede, siden de ødelagde deres eget værk. Senere så han i hertug Valdemar af Slesvig den egentlige ophavsmand til mordet, der ganske tydeligt var til hertugens fordel.

Helge Paludan erkendte i den store universitetsorienterede Danmarkshistorie fra 1977, at hverken gerningsmændene eller deres bagmænd lod sig identificere, medens Niels Skyum-Nielsen i sin Middelalderhistorie nogle år senere mente, at mordmotivet forblev uklart. Iøvrigt fandt han, at regeringen var klart skyldig i svigtende sikkerhedsforholdsregler, og at nogen måske havde røbet for morderne, hvor kongen ville være at finde. Kai Hørby overtog i den foreløbigt sidste større Danmarkshistorie fra Politiken og Gyldendals forlag fra 1989 Kjersgaards argumentation for, at de for mordet $\mathrm{d} ø \mathrm{~m}$ te var uskyldige; formålet med mordet var at forhindre, at Erik 6. Menved blev konge, og Hørby antyder, at dette kunne være en norsk interesse, da den norske konge og hans broder var dattersønner af kong Erik 4. Plovpenning.

Intet aktstykke gengiver dommen over de formodede kongemordere på danehoffet i maj 1287; den senere stadfæstelse af dommen i 1305 skelner mellem Arvid Bentsen som den egentlige drabsmand og otte andre som bagmænd for mordet. Blandt disse er de mest kendte marsk Stig, grev Jakob af Nørrehalland og Peder Jacobsen, der havde været guvernør over Fyn. En måned efter dommen i maj 1287 tog den norske konge og dennes broder de otte, men ikke Arvid Bentsen, til sig som deres mænd.

Det kan ikke nytte straks at ville identificere morderen; Dorothy Sayers' amatørdetektiv, historikeren Lord Peter Wimsey ville have sagt, at først, når man ved hvorfor, ved man også hvem. Derfor må vi gå en generation tilbage i tiden.

Måske på grund af konflikten mellem Erik 5.s fader Christoffer 1. og ærkebispen af Lund Jakob Erlandsen blev stormandsforsamlinger, de såkaldte danehoffer eller parlamenter regelmæssigt indkaldt i 1250 'erne, hvor politiske spørgsmål blev drøftet, og hvor domme blev afsagt i øverste instans. Christoffer døde i 1259, da Erik endnu var umyndig. Først omkring 1266 blev han erklæret myndig; indtil da havde hans moder Margrethe Sambiria været formynderstyrets ledende person. Også efter dette tidspunkt bevarede hun politisk indflydelse helt frem til 1282.

Den hyppige indkaldelse af rigsmøder ligesom i 1250 'erne blev genoptaget i de første år efter, at kongen var blevet myndig; parlamenter trådte således sammen i $1267,1268,1269$ og måske i 1271. Derefter blev et parlament først indkaldt til at mødes i oktober 1276. Kongens lille søn blev her fremstillet som tronfølger, og med undtagelse af marsken Stig Andersen gav stormændene ham kongenavn og svor ham troskab. Endvidere havde regeringen udarbejdet et udkast til feudalret, men været så uforsigtig at lade kongen udpege nævningene, også når han selv var part i sagen. Inderkredsen i rådet accepterede forslaget; men de andre deltagere i parlamentet fandt, at den anklagede burde udtage nævningene. Regeringen var åbenbart ikke parat til at acceptere denne 
ændring, og lovforslaget faldt. Sandsynligvis har regeringen villet sammenkæde anerkendelsen af tronfølgeren med lovforslaget til feudalret; dette må ses som et forsøg på at imødekomme de stormænds interesser, der havde mænd knyttet til sig, altså foruden kongen bisperne og de største verdslige aristokrater.

De ledende mænd i regeringen var drosten Uffe Nielsen (Neb), der havde dette embede fra 1268 til 1278/79, kansleren magister Niels Jyde (1267 til han døde i 1282) og marsken Stig Andersen, der åbenbart forlod regeringen efter parlamentet i 1276. I 1278 eller 1279 blev regeringen omdannet, idet drost Uffe blev afløst af Peder Nielsen Hoseøl; kontinuiteten blev sikret af Niels Jyde som kansler, og i 1281 blev marsk Stig igen optaget i regeringen. Denne bestræbte sig på - som hidtil - at undgå bortforleninger til kongeslægtens sidelinier. Til gengæld søgte den at give nogle af disses repræsentanter en vis politisk indflydelse. Erik, søn af hertug Knud af Blekinge, Valdemar Sejrs illegitime søn, optræder som brevvidne i 1280 sammen med drosten og kansleren, og året efter finder vi junker Jakob Nielsen, der også var sønnesøn af Valdemar Sejr, som brevvidne sammen med drost, kansler, marsk og kammermester.

Vi ved ikke, om det skyldes pres fra andre kredse, eller om regeringen af sig selv erkendte nødvendigheden af et systemskifte; det er en kendsgerning, at en kursændring fandt sted i 1282. I marts 1282 fandt det første parlament sted, hvor en forordning blev vedtaget, blandt andet med løfte om et årligt parlament og et forbud mod fængsling uden dom. En tilsvarende bestemmelse blev i England indført i 1215 og i Aragonien i 1282. I juli 1282 vedtog et nyt parlament en udførligere forordning ("håndfæstning"), der supplerede løfterne fra marts 1282.

Systemskiftet betød også, at andre personer kom til magten. Kansler Niels Jyde døde i sommeren 1282 og blev efterfulgt af biskop Jakob af Slesvig. Allervigtigst var det dog, at enkedronningen mistede sin indflydelse. Vi ved ikke, om hun selv trak sig tilbage, eller om hun blev tvunget ud. Efter alt at dømme forlod hun Danmark i efteråret 1282 for at slå sig ned i Mecklenburg, hvor hun året efter døde og blev begravet i klostret Doberan.

Den omstændighed, at systemskiftet i 1282 først og fremmest bestod $i$, at enkedronningen blev fjernet, og at der blev vedtaget regler, som ville være til fordel i hvert fald for stormændene, betyder formentlig, at vi skal se denne lovgivning som en bestræbelse på at stille en eventuel opposition tilfreds, fuldstændigt som man uden held havde forsøgt det i 1276 . Regeringen søgte at udvide sit støttegrundlag ved at inddrage greverne Albrecht $\mathrm{v}$. Gleichen, Albrecht v. Eberstein og Otto v. Ravensberg, der, selv om de var født i udlandet, også var danske godsejere. Grev Otto var onkel til junker Jakob Nielsen og må have været tilpas loyal til at være acceptabel for både regeringen og junker Jakob. Men stadig var der vigtige uløste problemer.

Endnu havde kong Erik 4. Plovpennings fire døtre ingen arv fået efter deres $\mathrm{i}$ 1250 myrdede fader; kun Sofie, der i 1260 giftede sig med kongen af Sverige, havde fået en del udlagt, medens de tre øvrige intet havde fået. De hidtidige regeringer havde søgt at forhindre udleveringen eller i hvert fald begrænse dens omfang. Juridisk kunne der ikke være tale om andet end, at de fire prinsesser skulle have deres arv. Det andet problem var opstået ved, at Val- 


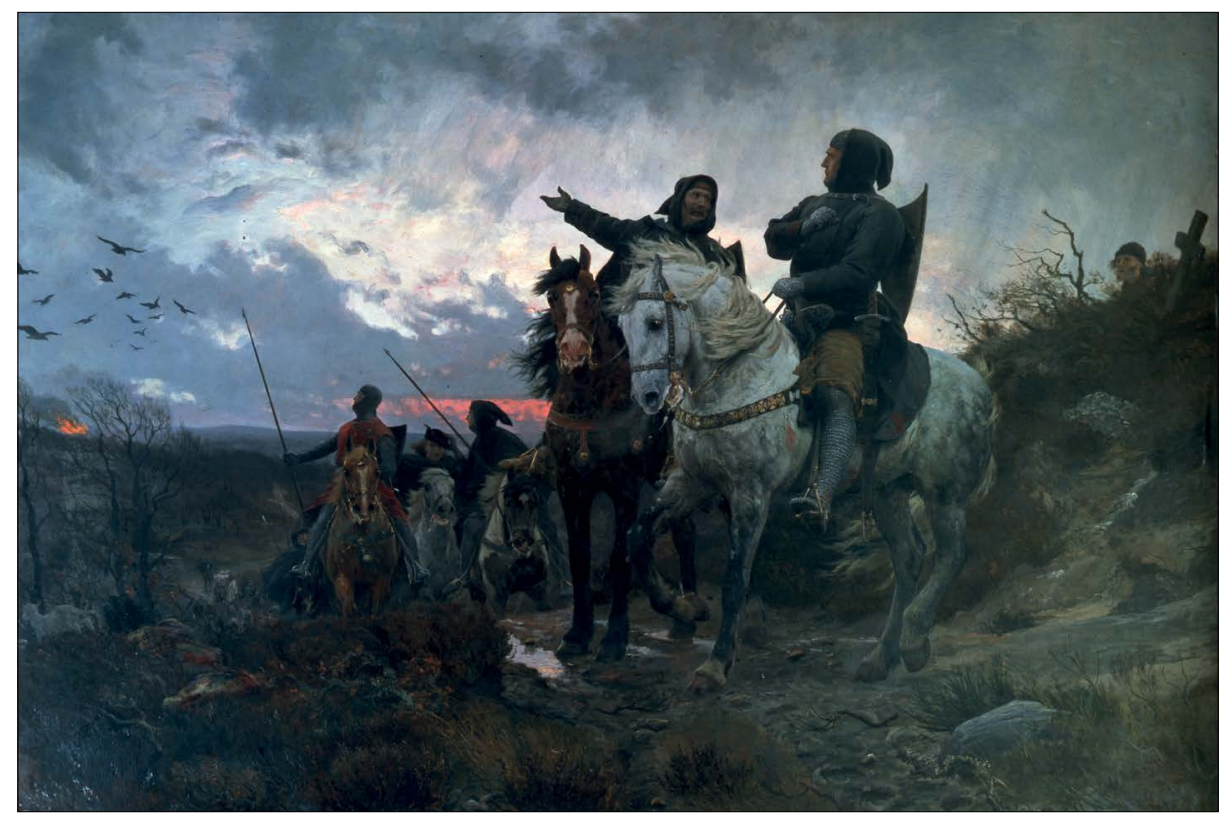

Nappe historisk korrekt, men alligevel et af de mest beromte danske historiemalerier: Otto Baches 'De sammensvorne rider fra Finderup efter mordet på Erik Klipping Skt. Cacilienat', 1882. Foto: Hans Petersen. Det Nationalhistoriske Museum, Frederiksborg.

demar 2. Sejr havde forsørget sine yngre sønner ved at give dem len (den ældste var blevet medkonge). Var der ikke tale om et arveligt len, kunne lensherren ved vasallens død inddrage lenet. Det samme gjaldt, når en ny lensherre tiltrådte styret; men i begge tilfælde var forudsætningen den nødvendige magt.

Systemskiftet betød en anerkendelse af disse kongextlingers arvekrav i form af udlæg af hele provinser som len. I 1283 fik junker Jakob Nielsen grevskabet Nørrehalland, Valdemar Eriksen fik Slesvig; samme år blev Stig Andersen som marsk erstattet af Lars Tygesen, der synes at have hørt til drost Peder Nielsens parti. Både grev Jakob og hertug Valdemar havde stærke krav på len; i grev Jakobs tilfælde blev Nørrehalland udlagt til ham som arv, og hertug Valdemar fik Slesvig som erstatning for, at kong Abels efterkommere mistede kongemagten til fordel for Christoffer 1.s efterkommere. Foreløbig synes regeringen at have villet affinde junker Erik Knudsen med embedet som drost i stedet for Peder Nielsen. Året efter kapitulerede regeringen: Junker Erik blev hertug af Sønderhalland; men Peder Nielsen kom ikke tilbage som drost. Det gjorde til gengæld hans forgænger Uffe Nielsen, og Stig Andersen blev atter marsk.

Den nye regering satte sig for at løse spørgsmålet om prinsessernes arv. I maj 1284 tilkendte et voldgiftsnævn med elleve stemmer mod en de fire kongedøtre deres fædrene arv $\mathrm{i}$ kongeriget og $\mathrm{i}$ hertugdømmet Slesvig. Samtidig blev et større lovkompleks vedtaget. I det følgende år afgjorde et nævn spørgsmålet om Als og 
om krongodset i hertugdømmet til hertug Valdemars utilfredshed. Han besatte det egenmægtigt, blev fængslet og først sat på fri fod efter at have udstedt en loyalitetserklæring i foråret 1286. Regeringen kunne nu se tilbage på betydelige resultater; der var blevet givet love om vigtige emner, og man var kommet til en forståelse med Erik Plovpennings døtre om arven, endelig havde efterkommerne af Valdemar 2.s yngre sønner fået tildelt len.

Kongemordet i november 1286 medførte et regeringsskifte. Marsk Stig og Uffe Nielsen mistede deres embeder, og Peder Nielsen vendte tilbage som drost. Til regeringskredsen hørte også den danske vasal fyrst Wizlav af Rügen, i hvert fald i 1287 og 1288 . Den nye regering må have set opgøret med det gamle styres mænd som sin vigtigste opgave. Selv om Uffe Nielsen måtte gå af som drost, skete der ham ikke mere. Marsk Stig og flere andre blev anklaget og dømt for kongemordet. Straffen var fredløshed og godsfortabelse på grund af majestætsforbrydelse, hvilket for eksempel betød, at regeringen kunne tage Nørrehalland fra grev Jakob, hvis den ellers var stærk nok.

Som nævnt af historikerne Erik Kjersgaard og Kai Hørby ville mordet for de angivelige kongemordere sætte hele den opfyldelsespolitik på spil, som de havde gennemført sammen med Erik 5. Glipping. Hertug Valdemar ville ikke med sikkerhed kunne opnå fordele af mordet, da også den nye konge ville insistere på hans loyale optræden. Derimod stod en anden opfattelse af den nødvendige politik i klar modsætning til opfyldelsespolitikken efter 1282.

Efter Valdemar 2. Sejrs død 1241 skulle det vise sig, at den stærke kongemagt forfaldt. Et tydeligt udtryk ser vi i svækkelsen af den såkaldte "Jyske" Lovs bestemmelser til ugunst for kongemagten, samt i den omstændighed, at regeringen efter systemskiftet i 1282 måtte opgive at få den anerkendt som rigslov.

Endvidere viste det sig, at de omfattende gaver til kirken og først og fremmest de privilegier, der fritog kirkegodset for afgifter og ydelser til kongen, havde nået et sådant omfang, at statsfinanserne blev truet. Kirkekampen handlede til dels om dette problem; Christoffer 1.s regering søgte på nogle punkter at skrue tiden tilbage som reaktion på en uheldig udvikling. Forsøgene på at inddrage fyrstelenene og ikke at udbetale arven til Erik Plovpennings døtre skulle lette presset på statsfinanserne. Systemskiftet kunne of fortalerne for den hidtidige politik dårligt ses som andet end et uforsvarligt og farligt udsalg af statens interesser, som kongen endog lod til at acceptere. Kunne man fjerne ham, måtte en formynderregering styre landet i nogle år, og med de rigtige personer ville man kunne vende tilbage til politikken før 1282. Heraf følger logisk, at motivet til mordet var ønsket om at vende tilbage til politikken fra før 1282.

Lyder dette overdrevent, behøver man blot tænke på andre politiske mord: I 1978 bortførte og senere myrdede De Røde Brigader den italienske politiker Aldo Moro, der havde gjort sig til talsmand for et samarbejde mellem De Kristne Demokrater og Kommunisterne, og i 1995 blev den israelske ministerpræsident Yitzhak Rabin myrdet af en israeler, der ville forhindre en fredsaftale mellem Israel og Syrien. Ønsket om et nyt systemskifte i 1286 var ikke mindre radikalt end årsagerne til Rabins og Aldo Moros død.

Kan man acceptere min argumentation, har vi nu årsagen til mordet, tilbage står at finde bagmanden. At væbneren 


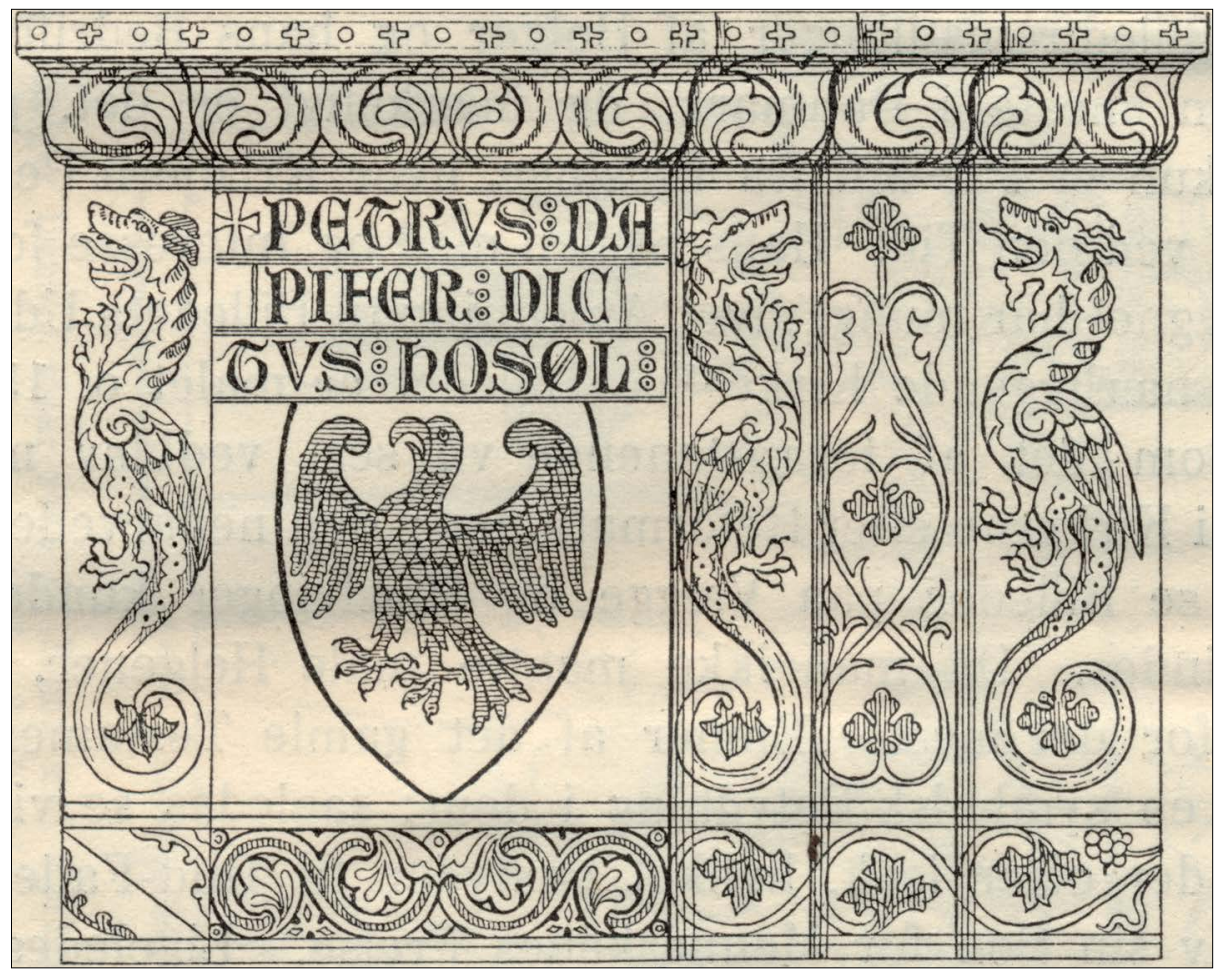

Vi ved ikke, hvordan drost Peder Nielsen Hoseøl (d. 1298) selv så ud, men hans våben er afbildet på våbenfrisen i Hvideslagtens store monument, Sorø Klosterkirke. 'Petrus Dapifer dictus Hosøl' betyder 'Drost Peder, kaldet Hoseøl', dvs. hoseband (strømperem). Gengivet efter De gamle Kalkmalerier i vore Kirker, red. J. Magnus-Petersen, 1900.

Arvid Bentsen var den, der gjorde det beskidte arbejde, er sandsynligt, om han var alene, ved vi ikke - han kan have tilføjet liget så mange sår, at det så ud, som om en hel gruppe havde deltaget. Den, der først og fremmest må ses som talsmand

\section{Noter}

1 Peter Heise: Drot og marsk. Tragisk opera i fire akter. Tekst af Christian Richardt / King and Marshal. Tragic Opera in Four Acts. Text by Christian Richardt. Udgivet af Niels Bo Foltmann, Peter Hauge, Niels Krabbe \& Axel Teich Geertinger. Det Kongelige Bibliotek / The Royal Library for den gamle politik, er drosten Peder Nielsen, der også i systemskiftets første år forhalede opfyldelsespolitikken.

Jeg anklager derfor tidligere drost Peder Nielsen Hoseøl for medvirken til mordet på kong Erik 5. Glipping.

\& Edition $S$ - music - sound - art:

Dansk Center for Musikudgivelse, 2013. Bind 1-2, xlvi, 869 ss. Ill. Folio. (Serien: DCM 12) ISMN 979-0-9001827-1-5. - Klaverpartitur / Vocal Score ved / by Per Salo. 2013, xvi, 421 ss. $4^{\circ}$ (Serien: DCM 15) ISMN 979-0-9001827-5-3. 


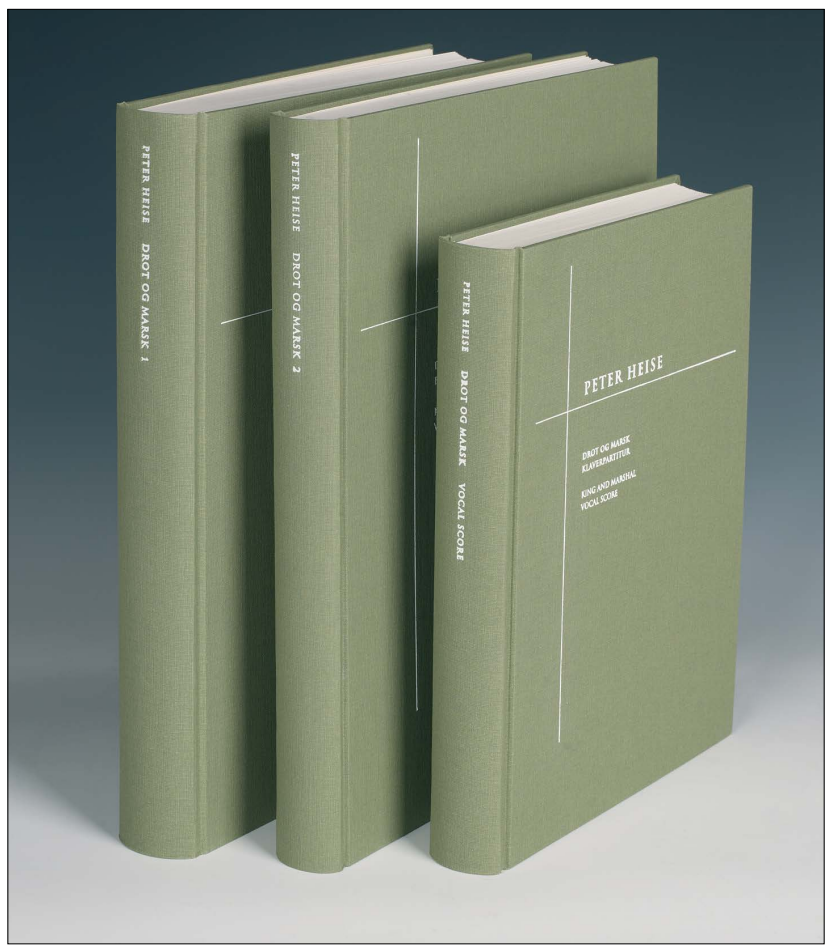

Artiklen er blevet til $i$

anledning af Dansk Center for Musikudgivelses presentation af Peter Heises store nationalromantiske operadrama Drot og Marsk, der handler om mordet på kong Erik Glipping.

Partituret til varket er $i$ to bind, det lille er klaverpartitur. Indbundet udgave kan erhverves hos Edition:S, men som andre publikationer fra Dansk Center for Musikudgivelse kan også denne downloades gratis fra adressen:

$<w w w \cdot k b . d k / d a / k b / n b /$ mtaldcm/udgivelser>

\section{Litteratur}

Bernhard Severin Ingemann: Erik Menveds Barndom Kbh. 1828.

Adam Oehlenschläger: Erik Glipping. I: Oehlenschlägers Tragiske Dramaer . Udg. af L. Liebenberg. Bind X. Kbh. 1859. (Oehlenschlägers Poetiske Skrifter. Udg. af L. Liebenberg. Bind XII).

Carsten Hauch: Marsk Stig. Kbh. 1850. Chr. Richardt: Drot og Marsk. 1878. 8. oplag. Kbh. 1940.

Kr. Erslev: Den senere Middelalder. I: Danmarks Riges Historie. Red. af Johs. Steenstrup, Kr. Erslev et al. Bind II. Kbh. 1898-1905.

Erik Arup: Danmarks Historie. Bind II. Kbh. 1932.

Erik Kjersgaard: Borgerkrig og Kalmarunion 1241-1448. I: Danmarks historie. Red. af John Danstrup og Hal Koch. Bind 4. Kbh.: Politiken, 1963
Samme: “Opklaring?” [Kronik], Skalk, nr. 6, 1971.

Helge Paludan: “Tiden 1241-1340”. I: Danmarks Historie. Red. af Aksel E. Christensen, H.P. Clausen, Svend Ellehøj \& Søren Mørch. Bind 1, Kbh.: Gyldendal, 1977.

Ebbe Kløvedal Reich: Festen for Cacilie. Den hemmelige beretning om et kongemord. Kbh.: Gyldendal, 1979.

Niels Skyum-Nielsen: Fruer og Vildmand. Dansk middelalderhistorie 1250-1340. Red. af Inger Dübeck, Kai Hørby \& Thomas Riis. Bind I. Kbh.: Akademisk Forlag, 1994 (posthumt udgivet).

Jørgen Matthiassen: Blodnatten. Kbh. 1988.

Kai Hørby: Velstands krise og tusind baghold 1250-1400. I: Gyldendal og Politikens Danmarkshistorie. Red. af Olaf Olsen. Bind 5. Kbh.: Gyldendal \& Politiken, 1989. 